\title{
Educating Medical Students in Receiving Feedback: The Importance of Self-Reflection [Letter]
}

This article was published in the following Dove Press journal:

Advances in Medical Education and Practice

\section{Danielle Oliveira \\ Emily Tulloch \\ Naining $X u(D)$}

Department of Medicine, Faculty of Medicine, Imperial College London, London, UK
Correspondence: Naining Xu

Emailnx216@ic.ac.uk

\section{Dear editor}

We read, with great interest, the article by Matthew et al, which explores the ability of medical students to receive feedback in a constructive manner, following a onehour training workshop. ${ }^{1}$ As fifth year medical students in the UK, we have found emphasis in our teaching is placed upon giving feedback rather than on how to appropriately receive feedback. Therefore, we commend the authors for bringing this issue to light. We believe the ability to receive feedback in an engaged and constructive manner is vital for learning and the improvement of clinical skills.

The method used by the authors is admirable; however, we feel this approach to training students in receiving feedback could be improved by implementing a selfreflective element. Self-reflection is an essential step in receiving feedback, as it is necessary for students to implement the feedback they receive and improve their clinical practice. ${ }^{2}$ Furthermore, Gibbs highlights the importance of self-reflection upon receiving feedback: without adequate self-reflection following feedback, individuals leap to premature conclusions regarding what happened, rather than achieving a deeper understanding of the feedback given. ${ }^{3}$ Medical schools utilise various models of self-reflection to equip students with a framework with which to reflect upon feedback. A self-reflective aspect could be incorporated through giving students a self-reflection template in the workshop, followed by a self-reflection task upon receiving their feedback.

Matthew et al correctly identify a key limitation in their work: comparing scores in the objective structured teaching exercise (OSTE) was insufficient to draw valid conclusions regarding the effectiveness of the workshop. The OSTE rubric used offers immediate assessment of the students' ability to receive feedback in a manner in keeping with their workshop training. However, it fails to assess if the students have processed this information and will apply it to their practice. As previously discussed, self-reflection is vital in receiving and acting upon feedback. Criteria exist for objectively assessing the quality of self-reflection, for example, the ICSE criteria from the Royal College of General Practitioners. ${ }^{4}$ We therefore suggest the use of a self-reflection exercise following each OSTE to evaluate the change in students' feedback-receiving ability.

We disagree with the authors' proposal of applying their approach to postgraduate trainees. As students progress through medical school, their engagement with feedback improves due to factors such as their increasing clinical skills and knowledge. ${ }^{5}$ Therefore, training of senior students and postgraduates in receiving 
feedback would produce little improvement upon their ability to receive feedback, when compared to younger students. Hence, the focus of training should not be upon postgraduates, but instead on younger students who are yet to develop the capacity to fully appreciate and assimilate feedback they receive.

Matthew et al highlight a crucial issue which will inevitably impact all medical students during their training: the importance of learning to receive feedback. However, for students to be able to use the feedback they receive effectively and improve their practice, it is necessary to equip them with the ability to reflect upon the feedback they receive.

\section{Disclosure}

The authors report no conflicts of interest in this communication.

\section{References}

1. Matthew A, Hall M, Parra JM, et al. Receiving real-time clinical feedback: a workshop and OSTE assessment for medical students. Adv Med Educ Pract. 2020;11:861-867. doi:10.2147/AMEP.S271623

2. Hardavella G, Aamli-Gaagnat A, Saad N, Rousalova I, Sreter KB. How to give and receive feedback effectively. Breathe. 2017;13:327-333. doi:10.1183/20734735.009917

3. Husebø S, O'Regan S, Nestel D. Reflective practice and its role in simulation. Clin Simul Nurs. 2015;11(8):368-375. doi:10.1016/j. ecns.2015.04.005

4. Royal College of General Practitioner WPBA Standards Group. Hallmarks of good practice in information recording in the ePortfolio; 2020. Available from: https://www.rcgp.org.uk/-/media/ Files/GP-training-and-exams/WPBA/LLE/RCGP-Hallmarks-of-goodpractice-information-recording-ePortfolio.ashx?la=en. Accessed December 21, 2020.

5. Murdoch-Eaton D, Sergeant J. Maturational differences in undergraduate medical students' perceptions about feedback. Med Edu. 2012;46:711-721. doi:10.1111/j.1365-2923.2012.04291.x

Dove Medical Press encourages responsible, free and frank academic debate. The content of the Advances in Medical Education and Practice 'letters to the editor' section does not necessarily represent the views of Dove Medical Press, its officers, agents, employees, related entities or the Advances in Medical Education and Practice editors. While all reasonable steps have been taken to confirm the content of each letter, Dove Medical Press accepts no liability in respect of the content of any letter, nor is it responsible for the content and accuracy of any letter to the editor.

\section{Publish your work in this journal}

Advances in Medical Education and Practice is an international, peerreviewed, open access journal that aims to present and publish research on Medical Education covering medical, dental, nursing and allied health care professional education. The journal covers undergraduate education, postgraduate training and continuing medical education including emerging trends and innovative models linking education, research, and health care services. The manuscript management system is completely online and includes a very quick and fair peer-review system. Visit http://www.dovepress.com/testimonials.php to read real quotes from published authors. 